\title{
Bridge pier scour in cohesive soil: a review
}

\author{
Y SONIA DEVI and A K BARBHUIYA*(i) \\ Department of Civil Engineering, National Institute of Technology, Silchar 788 010, India \\ e-mail: akbarbhuiya@yahoo.com
}

MS received 15 December 2015; revised 16 November 2016; accepted 18 February 2017; published online 2 August 2017

\begin{abstract}
Bridge failure due to local scour has stimulated the enthusiasm of many researchers to study the causes of scouring and to predict the ultimate scour depth at bridge foundation. A brief review of the state of artwork of investigation conducted on local scour at bridge pier in cohesive bed material is presented. Scour process and mechanism at bridge pier in cohesive and noncohesive soil are presented. The effects of parameters influencing local scour around bridge pier is discussed. Empirical equations for predicting ultimate scour depth at bridge pier embedded in cohesive soil are outlined. Comparisons of the equations are made considering two examples: one under laboratory condition and another under field condition.
\end{abstract}

Keywords. Local scour; bridge pier; cohesive; hydraulics.

\section{Introduction}

Three dimensional boundary layer separations around the bridge foundation causes reduction of the river bed level and is termed as local scour. Local scour is the main cause of bridge failure [1]. Bridge damage has caused significant life and financial losses. As bridge scour is responsible for $60 \%$ of river bridge failure, U.S. Federal Highway Administration (FHWA) considers this as an important engineering concern [2]. The Scholarie Creek bridge failure that killed 10 people in New York in 1987 prompted enhanced sponsored research of about $\$ 11$ million [1].

Many significant research works have been done on the scour of noncohesive sediment [3-8]; Guo [29]; $[9,10,11,12]$. Few researchers have studied scour around pier on cohesive soil because of the complicated cohesive behaviour [1, 13-25]. In addition to the complex mechanical phenomena, the chemical and physical bonding of the colloid clay particles is involved in the scour of cohesive materials [21]. Previously, solutions for cohesionless soil were used for calculation for cohesive soil. Recently, many researchers revealed that scour around bridge pier in cohesive soil are smaller than those in non-cohesive soil. So, such an approach would lead to a foundation that is considered to be deeper than necessary or installation of unwanted scour countermeasures at existing bridge and therefore costlier than necessary. It is thereby believed that this paper will give important information to new as well as current researchers in this field.

*For correspondence

\section{Scour mechanism}

Introduction of pier into the main channel flow changes the flow pattern into complex three-dimensional vortex flows. Local scour is the reduction of original bed level around the hydraulic structure caused by the three-dimensional boundary layer separations around the structure. Several researchers have reported on the complex flow pattern around the bridge pier embedded in cohesionless soil. Researchers include Melville [26], Dargahi [27], Dey et al [3], Guo [29], Kumar and Kothyari [9]. Figure 1 shows the component of flow generated around the bridge pier. These are the down-flow and surface roller at the upstream pier nose, horseshoe vortex at the upstream pier side near the bed and wake vortex at the downstream wake region.

The flow set up a pressure gradient $(\partial P / \partial \theta)$ when it interacts with the pier on the upstream face at $0^{\circ} \leq \theta \leq 90^{\circ}$, where $\theta$ is the angle from the leading pier face. This is due to the stagnation of the upstream approach flow [29]. Using the concept of Bernoulli's equation between the approach flow and the leading edge, Guo [29] found that the stagnation point is at $10 \%$ of the flow depth from the bottom at the initiation of scour. At the beginning of scour a large portion of the stagnation flow turn up forming the up-flow (or surface roller), while a small portion of the stagnation flow become down-flow. When the down-flow impacts the sediment bed, another stagnation point forms at the bed where the maximum pressure deflects water upstream of the pier forming a micro horseshoe vortex.

Using the concept of Prandtle's boundary layer theory, Guo [29] interpreted that no sediment moves downstream from the leading edge at the initiation of scour as the pressure gradient is zero at the stagnation point. The 


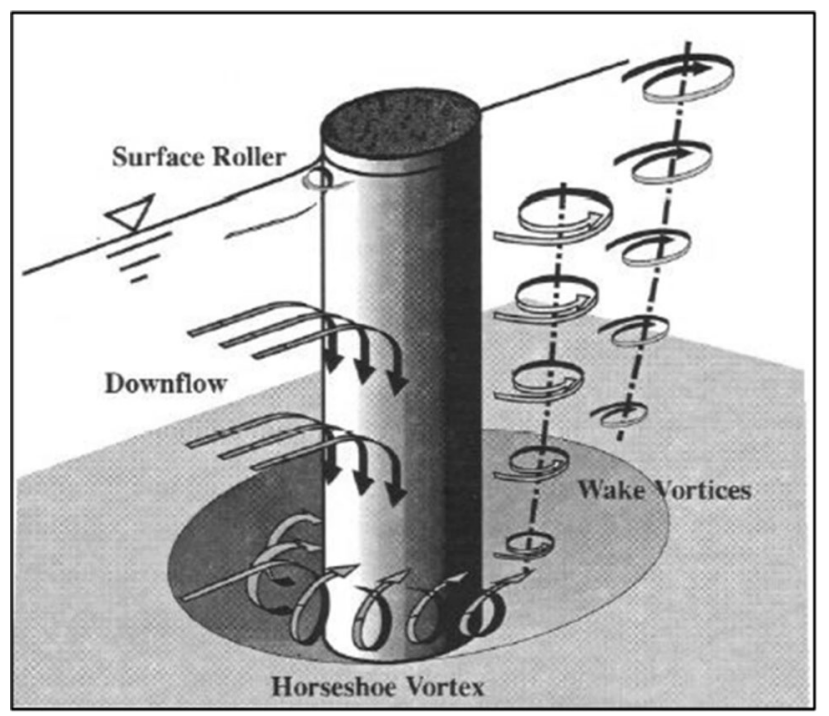

Figure 1. Flow field around a circular pier (after Melville and Coleman [28]).

maximum pressure gradient occurs at $\pm 45^{\circ}$ from the leading pier face and hence the scours begin at the pier side and propagate towards the pier nose around the upstream perimeter of the pier. Melville [26] and Ahmad and Rajaratnam [30] measured the flow field around the pier and have concluded that at the sides of pier the average shear is 10-12 times than that of the approach flow and at the nose it is 4 times irrespective of other parameters.

The down-flow acts as a vertical jet, which loosens the sediment bed, and the horseshoe vortex transports the dislodged sediment particle away past the pier. Melville [26] found that, once the scour is initiated, more fluid attains the vertical downward component thereby increasing the size and strength of the vortex, thus increasing the strength of the down-flow. As the hole enlarges, the horseshoe vortex grows in diameter and moves down into the hole. With further increase in scour depth, Melville's measurement indicates that the circulation associated with the horseshoe vortex continues to increase as equilibrium is approached, but at a decreasing rate. This is because of the increase in scour cross-sectional area. At the initial stage, excavation is almost vertical and the edge of the scour hole is often very sharp. As the scour approach the equilibrium, avalanches of the bed material occur from farther up the side of the hole, causing the hole to widen and thus maintain the slope angle. At the upstream, the shape of the hole resembles an inverted right cone whose axis coincides with that of the pier, with the slope angle equivalent to the dynamic angle of repose of the sediment bed [31].

A favourable pressure gradient generates at the downstream of the pier and along the vortex line upwards. This causes the sediment to move into the wake region through the bed load and suspended load to a low-pressure area [29]. According to Melville [26], the vortex shedding frequency depends primarily on the obstruction sizes and the flow velocity. In the wake region, if the sediment particle that was swept around the sides of the pier interacts with the wake vortex, it can be brought upwards in the water column by the upward flow associated with the centre of the vortex and transported downstream, where it is eventually deposited. If the sediment is swept directly behind the pier, it experiences the relatively calm wake region between the shedding vortices where it settles down to form the characteristic mound behind the pier.

Though the gravity forces and the submerged density of the soil are the main resistance force to erosion in cohesionless soil, the net attractive inter-particle surface force controls the resistance to erosion in cohesive soil [23]. Further, Kumar and Kothyari [9] observed that due to the flow separation, the shear stress at the upstream nose of the pier is about four times that of the approach flow, whereas the shear stress magnifies up to 11 times that in the approach flow at pier sides. Kothyari et al [32] conducted laboratory experiments in cohesive sediment-containing gravel and studied pier scour at wake zone. They observed no deposition of sediment at wake zone and thereby developing larger scour depth at wake and sides of the pier. Working on clay-sand mixed bed, Debnath and Chaudhuri [16] envisaged that it is the combined effect of shearing resistance of soil bed and the applied shear stress generated by flow that determines the location of maximum scour depth at the pier and hence proposed some empirical relations for the same. They conceptualised that scour initiates at the sides of the pier and then propagates through downstream.

\section{Classification of local scour}

In case of cohesionless soil, local scour can be classified as live-bed scour and clear-water scour (e.g. [5, 33]. When sediment from upstream is not transferred by the upstream approach flow into the scour hole, clear-water scour is said to occur. It leads to slow increase of scour depth until an equilibrium state is reached. While in case of live-bed scour, sediments are continuously delivered into the scour hole by the approach flow. In live-bed scour, the flow velocity and strength of the vortex are very large with respect to the shear strength of the sediment bed and hence the scour hole develops faster. In live-bed scour, the scour depth fluctuates around an equilibrium value, which is because of the interaction between sediment supplied and removed from the scour hole. Moreover, the scour depth also fluctuates in case of fine-bed sediment due to the movement of bed form. According to Shen et al [34], the amplitude of the fluctuation is less than $1 / 2$ the height of the bed form. Clear-water scour increases almost linearly at the initial time, but the rate of scour reduces with time and takes a longer period to reaches to its maximum value than 
live-bed scour, as shown in figure 2. The cohesive material remains in suspension once they are eroded and hence clear-water scour is always occurring in cohesive bed [21]. An important parameter that differentiates live-bed scour from clear-water scour is the flow intensity $\left(V / V_{c}\right)$. Clearwater scour occurs when $V / V_{c} \leq 1$, while live-bed scour is said to occur when $V / V_{c}>1$, where $V$ is the upstream approach flow velocity and $V_{c}$ is the critical velocity of flow [8]. Figure 3 illustrates the scour depth behaviour as a function of flow intensity. Figure 2 shows that the equilibrium scour depth is greater in clear-water scour than in live-bed scour, while in figure 3, as mentioned in Molinas and Hosny [21], the threshold peak is less than the second maximum peak of live-bed scour. This might be because the observed maximum scour depth in live-bed condition as in figure 2 did not consider the depth of the loose sediment transported from the upstream. Loose sediment around the structure has no strength to support it. So, in field condition, the equilibrium scour depth in case of live bed should also include the additional depth of loose sediment and, if it is so, the maximum live-bed scour depth might be equal to or greater than clear-water scour depth. Details of the influence of flow intensity are discussed in the later section.

\section{Clay properties}

To understand the fundamental factors affecting the erosion rate of cohesive soil under a given flow condition, knowledge of nature and behaviour of clay particle is necessary. The crystalline minerals whose surface activity developed plasticity and cohesion are called clay mineral. There are four main groups of clay minerals: Kaolin, montmorillonite, illite and playgorskite. Chemically, the clay minerals are silicates of aluminium and/or iron and magnesium. Some of them also contain alkalies and/or alkaline earths as

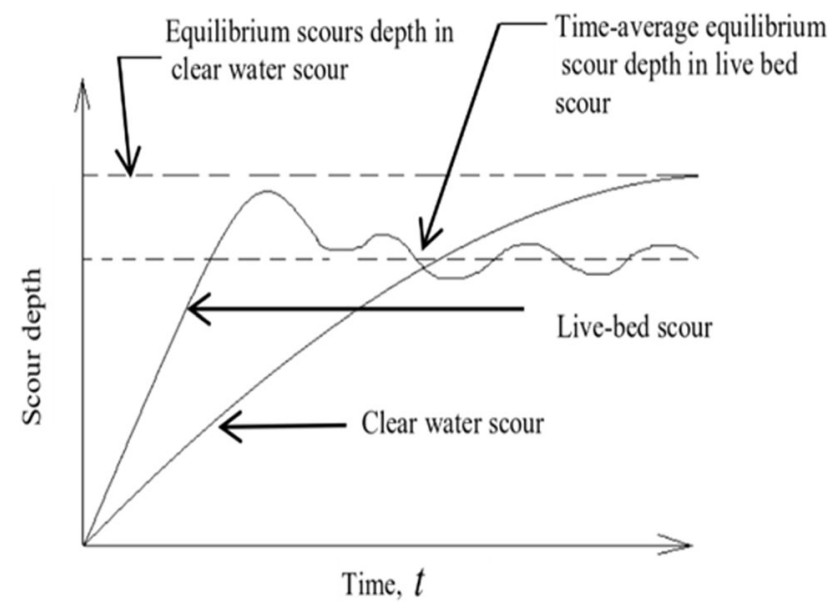

Figure 2. Scour depth versus time plot (after Chabert and Engeldinger [33]).

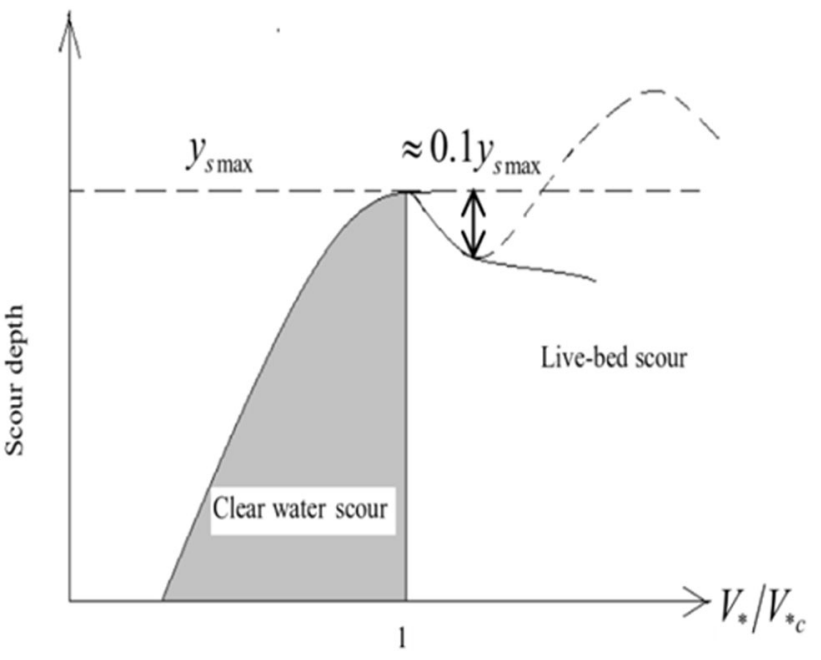

Figure 3. Scour depth in terms of shear velocity (after Molinas and Hosny [21]).

Table 1. Atterberg limits and cation-exchange capacity (after Link et al [20]).

\begin{tabular}{lcccc}
\hline $\begin{array}{l}\text { Dominant clay } \\
\text { mineral }\end{array}$ & $\begin{array}{c}\text { Liquid } \\
\text { limit }(\%)\end{array}$ & $\begin{array}{c}\text { Plastic } \\
\text { limit }(\%)\end{array}$ & $\begin{array}{c}\text { Plasticity } \\
\text { index }(\%)\end{array}$ & $\begin{array}{c}C E C \text { (meq/ } \\
100 \mathrm{~g})\end{array}$ \\
\hline Montmorillonite & $140-710$ & $50-100$ & $67-656$ & $80-150$ \\
Illite & $80-120$ & $45-60$ & $33-67$ & $10-40$ \\
Kaolinite & $<60$ & $29-37$ & $11-21$ & $3-15$ \\
\hline
\end{tabular}

essential components. Clay particles are flat shaped and carry negative electric charge on their surface. In engineering practice, clay and silt particles, which occur in size smaller than $0.002 \mathrm{~mm}$, and between $0.075 \mathrm{~mm}$ and $0.002 \mathrm{~mm}$ respectively, are typically referred to as cohesive soils.

Clay minerals have the quality of adsorbing certain anions and cations, and maintaining them in an exchangeable state. These anions and cations can be replaced by other anions and cations by treatment with such ions in water solution. A characteristics gauge of clay mineral cohesion is the cation-exchange capacity (CEC). CEC is the total number of cations that a soil can hold at a given $\mathrm{pH}$ value. CEC of clay mineral is expressed as milliequivalent of exchangeable ion per $100 \mathrm{~g}$ of clay. The higher the CEC of clay mineral results the greater the cohesion. The range of Atterberg limits along with its CEC for three important types of clay minerals is shown in table 1 .

The incipient motion and the scour of sediment need to overcome the two inter-particular forces, that is, effective gravity and cohesive or surface force $[35,36]$. Cohesion is due to electrochemical forces acting on the particle surface. Cohesion leads to particle aggregation and it governs the transport, erosion and accumulation of fine sediment. For cohesive sediments, the surface physio-chemical forces are 
greatly important as compared to that of particle weight. This is due to the large specific surface area (surface area per unit volume).

\section{Parameters affecting local scour}

Fluid parameters, flow conditions, stream bed materials and pier characteristics are the main variables affecting the pier scour phenomenon. Time of scour is also an important parameter for the given conditions of these variables. Parameters influencing the scouring phenomenon are listed as follows:

1. Parameters characterising the approach flow: undisturbed mean velocity, depth of approach flow, shear velocity, roughness and stream-bed slope.

2. Parameters characterising the channel geometry: width and slope, cross-sectional shape.

3. Parameter characterising the bridge pier: pier shape, size, flow attack angle, surface condition and protection system.

4. Parameter characterising the fluid: temperature, gravitational acceleration, viscosity and density of fluid.

5. Parameters characterising the bed material:

a. Non-cohesive soil: grain size distribution, mass density, median size and sediment fall velocity.

b. Cohesive soil: chemical and physical properties of cohesive soils.

6. Time of scouring.

The process of pier scour found in non-cohesive bed materials for different condition of flow, pier and sediment characteristics is reasonably well understood at present. However, only limited researches have been carried out on scour around pier in cohesive bed. Types and percentages of clay present in sediment mixture, water content, plasticity index, bed shear strength and unconfined compressive strength are the significant parameters influencing the pier scour in cohesive bed reported so far. Several researchers considered bed material characteristics in their studies for pier founded in cohesive bed [13, 15-18, 20-22, 32, 37].

\section{Influence of parameters on scour depth}

This section lays more emphasis on scour in cohesive soil.

\subsection{Upstream approach flow velocity}

The influence of flow velocity $V$ in the formulae to predict maximum scour depth is incorporated in the form of shear velocity or flow Froude number and Reynolds number. Working with non-cohesive soil, Chabert and Engeldinger
[33] established that the scour depth increases linearly with $V$ in clear-water scour until it reaches a stable maximum value. This limiting scour depth is called threshold peak. The threshold peak or transition from clear-water to livebed condition occurs when approach velocity equals critical velocity for sediment particles. Live-bed scour occurs when $V / V_{c}>1$.

In case of live-bed scour, Shen et al [34] found that with increase in Reynolds number the maximum scour depth decreases. This is due to the delivery of sediment into the scour hole by the upstream flow. Melville and Sutherland [38] introduced an armour velocity $V_{a}$ for non-uniform sediment. The transition from clear-water scour to livebed scour is identified by $V_{a}$. Hence, for uniform sediment, it is equal to critical velocity $V_{c}$. For non-uniform sediments, if $V / V_{a}>1$ live-bed condition is said to exist; while if $V / V_{a}<1$ clear water condition exist. Under the live-bed scour condition, Melville [39] concluded that with the increase in flow velocity the scour depth initially reduces just next to the threshold peak and then increases again towards a second maximum. The second peak occurs at about the transitional flatbed stage of sediment transport on the channel bed and is termed as live-bed peak, and the velocity at this peak is termed as live-bed peak velocity [8]. After the threshold peak $\left(V / V_{c}=1\right)$, the bed form is either ripple or dunes. As $V / V_{c}$ increases, the configuration of bed changes to plain and antidunes and simultaneously the live-bed scour depth increases as the transported sediment is being washes through the scour hole. With the further increase in $V / V_{c}$, the sediment particle that is being transported from the upstream does not take part in scouring as these sediments are swept over the scour hole and this condition is identical to clear-water scour condition.

Experimental result of Molinas and Hosny [21] in a mixture of cohesive and non-cohesive soils and in unsaturated cohesive soils shows that the dimension of the scour holes increases with increasing flow discharge and at the same water depth the increase approach velocity or Froude number eroded more material from around the pier. Rambabu et al [23] and Najafzadeh and Barani [22] evaluated the ultimate maximum scour depth $\left(y_{s \max }\right)$ using a theoretical hyperbolic model. The data employed in the model were collected from short-duration test $(4 \mathrm{~h})$ conducted in cohesive soil. They found that the ultimate scour depth increases with increase in flow Froude number $F_{r}=(V / \sqrt{g h})$ where $g$ is the gravitational acceleration and $h$ is the flow depth. Figure 4 shows the variation of $y_{s m a x} / h$ as a function of $F_{r}$ base on the experimental data conducted on cohesive bed by different researchers.

Debnath and Chaudhuri [15] considered pier Froude number $\left(F_{p}\right)$ for estimating non-dimensional maximum 


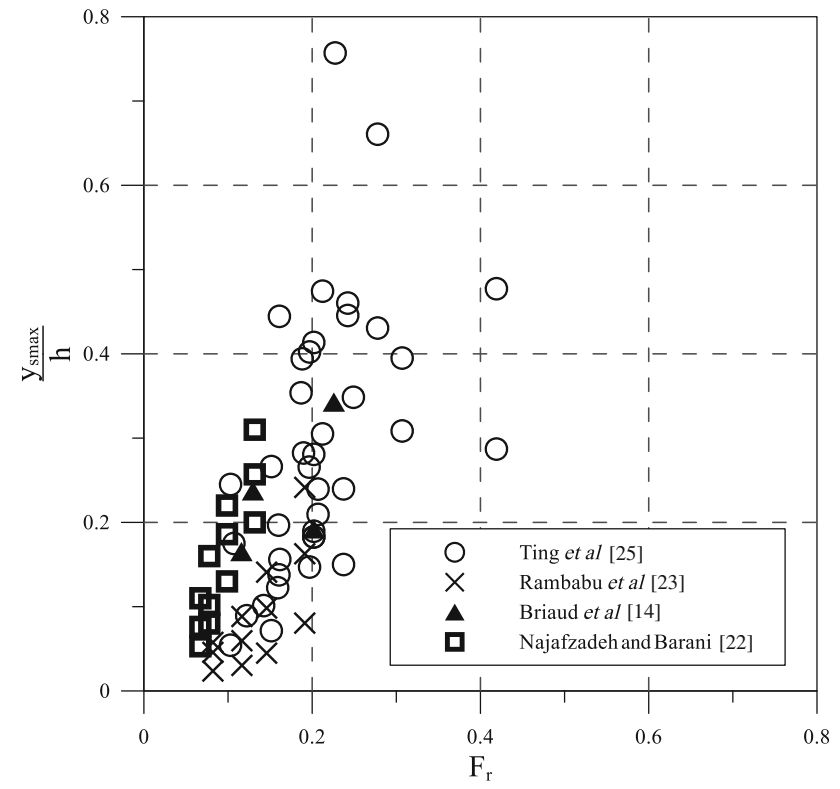

Figure 4. Ultimate scour depth as a function of flow Froude number with $0.025 \mathrm{~m} \leq b \leq 0.16 \mathrm{~m}$.

scour depth and maximum scour hole diameter for pier founded in clay-sand mixed bed. Figure 5 shows the variation of non-dimensional maximum scour depth as a function of pier Froude number chosen for $100 \%$ clay. Figure 5 reveals that as pier Froude number increases the maximum scour depth increases. Reynolds number $\left(R_{p}\right)$ influences the rate of vortex shedding; however, for fully turbulent flow, viscous effect is normally assumed to be negligible. Therefore, effects of Reynolds number in pier scour study is generally neglected as the flow at the bridge pier is fully turbulent [40]. Hence, Molinas and Hosny [21]; Debnath and Chaudhuri $[15,16]$ and Najafzadeh and Barani [22] did not consider $R_{p}$ in the development of their empirical equation. The range of $R_{p}$ considered in the test by Najafzadeh and Barani [22] is 22,600-14,100, and that of Debnath and Chaudhuri [15, 16] is 59,722-99,272. According to Sumer et al [41], Reynolds number has some effects on the scour depth at the wake region if the model surface is hydraulically smooth, but it is almost unaffected for rough surface. Briaud et al [1] concluded that the Reynolds number is found to be a better indicator of maximum scour depth $y_{\text {smax }}$ than the Froude number for pier in cohesive bed. Briaud et al [1]; Ting et al [25] and Kho et al [18] considered pier Reynolds number in their study (figure 6). They concluded that the scour hole shape correlates well with the pier Reynolds number. The scour depth is identical all around the pier at low Reynolds number $\left(10,000 \leq R_{p} \leq 15,200\right)$; and the scour hole mainly develops at the wake region for higher Reynolds number $\left(15,300 \leq R_{p} \leq 84,840\right)$ producing a lesser scour at the pier nose. According to them, the relative water depth and the Froude number have no significant effect on the

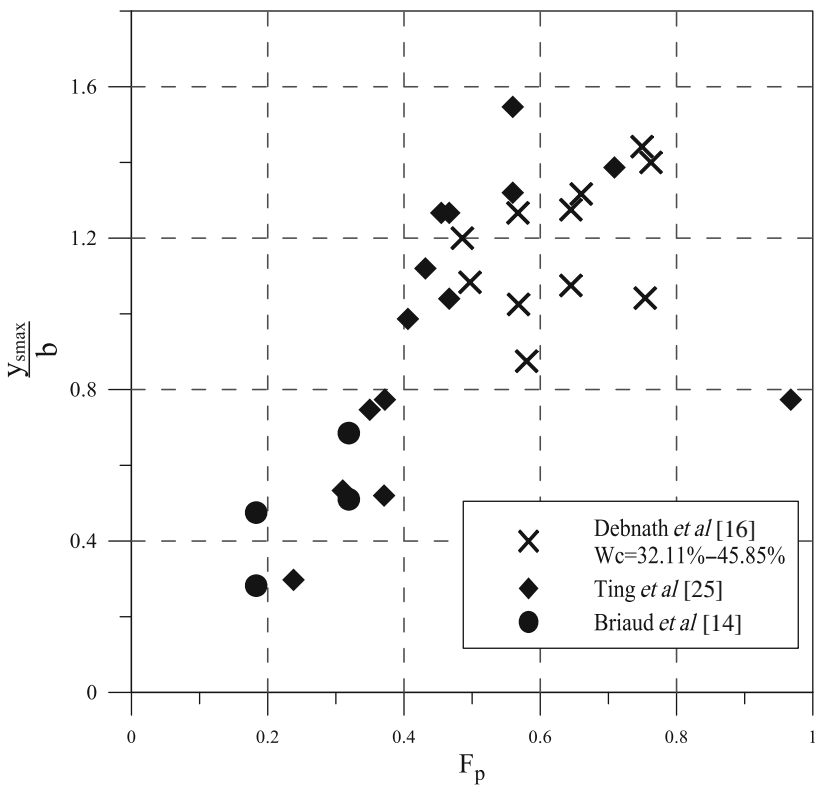

Figure 5. Scour ratio as a function of pier Froude number for $100 \%$ clay.

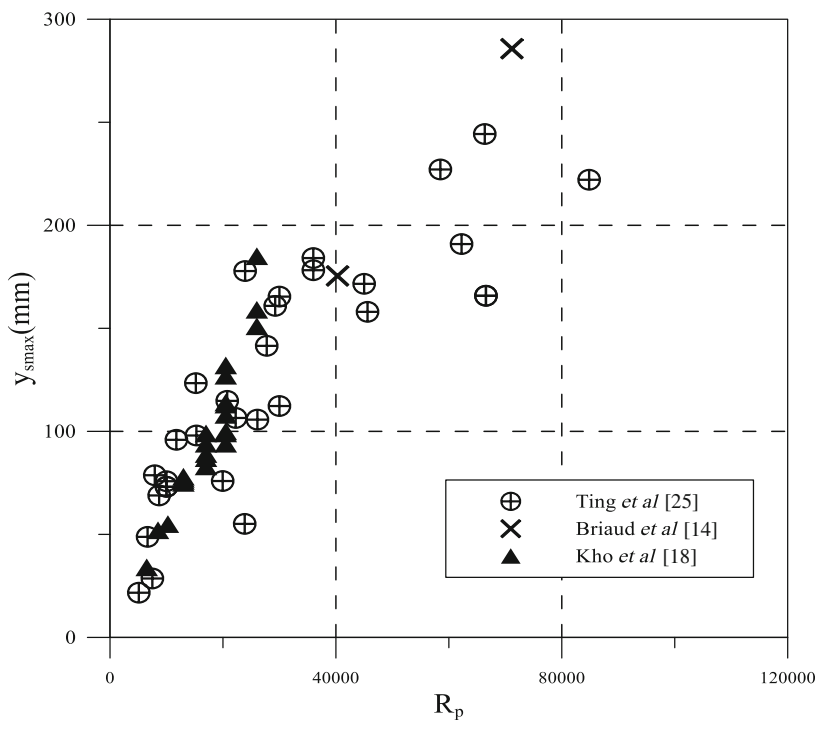

Figure 6. Maximum scour depth as a function of pier Reynolds number $\left(R_{p}\right)$.

maximum scour depth for a pier in cohesive bed. They added that the Froude number is a significant parameter if the force of gravity has an important effect on the flow. Froude number is mainly employed in establishing the water-surface profile next to a pier, which in turn affects the flow field and the scouring process. Li et al [19] conducted flume test on porcelain clay to explore the shallowwater effect on pier scour in clay. Under shallow-water condition, pier scour in clay has a discount factor very similar in sand.

According to Briaud et al [14], the maximum scour depth in clay does not depend on water depth when approach flow 


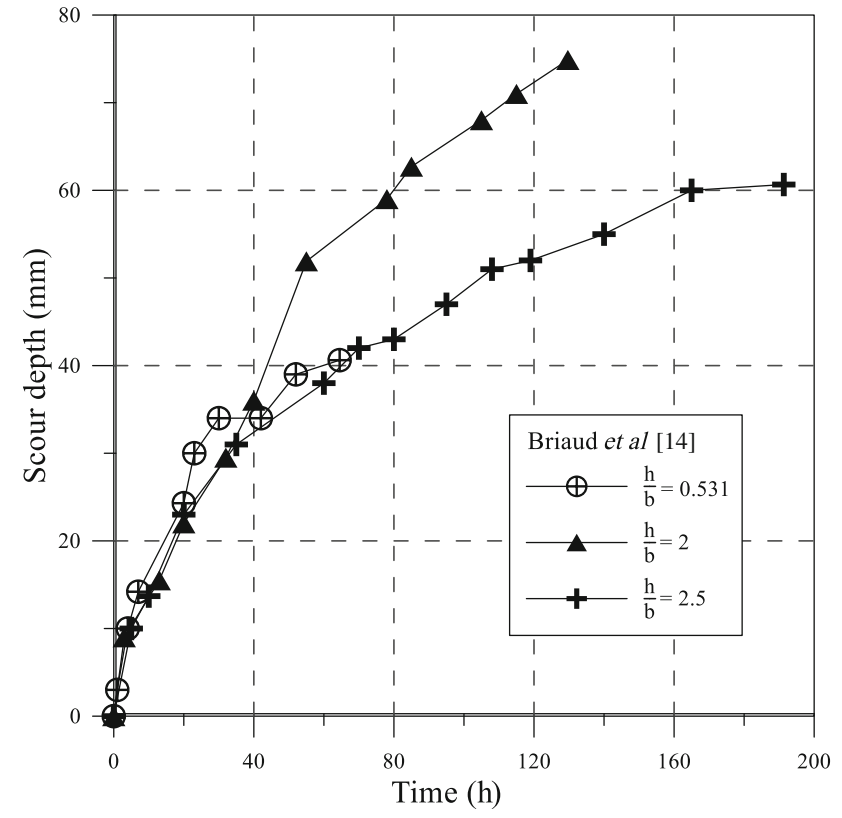

Figure 7. Pier scour versus time for shallow water with $V=0.4 \mathrm{~m} / \mathrm{s}$ (after Briaud et al [14]).

depth to pier diameter ratio $(h / b)>2$. Figure 7 illustrates the temporal development of scour depth under shallow water condition taken after Briaud et al [14]. Briaud et al [14] concluded that under shallow water condition, the rate of scour is faster in shallower water; however, the scour depth is lesser than that of deeper water, and the time taken to reach the equilibrium is also lesser. According to them, this is because the losses of eroding energy more rapidly in shallow water than in deep water with the increase in scour depth.

It can be concluded that scour depth depends on flow depth at shallow water $(h / b<2)$ only, because at shallow water depth, even the formation of lesser scour depth produces additional flow area, which compensates higher percentage of flow blockage area $(b \times h)$ compared to higher flow depth $(h / b>2)$ producing little more scour depth. But at higher flow depth, the maximum blockage flow is compensated by accelerated flow along the sides of the pier above the bed level. Moreover, the formation of horseshoe vortex, responsible for scour, may not form completely at shallow flow depth. Thus, there will be increase of scour depth with the increase of flow depth at shallow water depth $(h / b<2)$.

\subsection{Shape of the pier and angle of attack}

Working with non-cohesive soil, Tison [42] found that rectangular pier gives the maximum scour, while a splayed pier with a wide base produces less scour. According to Larras [43], minimum scour depth occurs on lenticular shape pier and maximum scour on rectangular
Table 2. Shape factors of different pier shape.

\begin{tabular}{cc} 
Pier shape & Shape factor \\
\hline Rectangular $(l / b=2-6)$ & 1 \\
Round nosed & $1.1-1.25$ \\
Sharp nosed & 1 \\
Lenticular $(2: 1,3: 1,4: 1)$ & $0.43,0.79,0.70$ \\
Joukowsky $(4: 1,5: 1)$ & $1.0,0.8$ \\
& \\
Triangular: & \\
$15^{\circ}$ apex angle & 0.45 \\
$60^{\circ}$ apex angle & 0.75 \\
$90^{\circ}$ apex angle & 0.88 \\
$120^{\circ}$ apex angle & 0.94 \\
$150^{\circ}$ apex angle & 1 \\
&
\end{tabular}

pier. However, the advantages of the former shape disappear for the angle of attack of $10^{\circ}$ or more. Paintal and Garde [44] conducted experiments on pier with upstream triangular noses having different apex angle $\left(15^{\circ}\right.$ to $\left.180^{\circ}\right)$ and their results indicate that the maximum scour depth decreases with decreasing apex angle. Shen et al [34] classify pier shape into two categories; namely, bluntnosed pier and sharp-nosed pier. In the former case, the maximum scour depth occurs at the pier nose, while in latter case, it occurs near the downstream end. This is because of the strong and weak horseshoe vortex systems, respectively. The length of the pier and downstream pier shapes has a minimum effect on the scour depth if a bluntnosed pier is aligned with the approach flow. According to Dietz [45], maximum scour depth is independent of attack angle for centre-line spacing larger than three times of the pier diameter. Melville and Raudkivi [46] conducted laboratory experiments on a non-uniform pier and concluded that the ratio of pier diameter to foundation size $\frac{b}{b_{*}}$ and depth of foundation top from original bed level $Y$ are the parameters that govern scour in non-uniform pier. They observed that minimum scour occurs in the range $0 \leq \frac{Y}{b} \leq 2.4$. Laursen and Toch [4], Chabert and Engeldinger [33], Paintal and Garde [45] and Melville [6] considered the shape effect of the pier on scour depth in terms of shape factor. The value of relative shape factor for different shape is shown in table 2. From the table it is observed that rectangular shape produces maximum scour and lenticular shape produces minimum scour. As per Richardson and Davis [47], the value of coefficient for flow attack angle for different pier length by width ratio is shown in table 3 . 
Table. 3. Value of coefficient for flow angle of attack.

\begin{tabular}{lccc}
\hline Angle & $l / b=12$ & $l / b=8$ & $l / b=4$ \\
\hline $0^{\circ}$ & 1 & 1 & 1 \\
$15^{\circ}$ & 2.5 & 2 & 1.5 \\
$30^{\circ}$ & 3.5 & 2.75 & 2 \\
$45^{\circ}$ & 4.3 & 3.3 & 2.3 \\
$90^{\circ}$ & 5 & 3.9 & 2.5 \\
\hline
\end{tabular}

Briaud et al [14] studied pier shape effect on scour in cohesive soil. They considered rectangular piers of length to width ratio $(l / b)$ ranging from $1: 1$ to $12: 1$ having piers installed with a zero-degree attack angle. Taking a circular pier of diameter equal to the width of rectangular pier as reference pier, they defined shape correction factor $K_{s h}$ as the ratio of maximum scour depth for a given shape over the maximum scour depth for circular pier. Briaud et al [14] concluded that as long as $l / b>1, K_{s h}$ of 1.1 is to be considered for evaluating maximum scour depth around rectangular pier in both sand and clay. Debnath and Chaudhuri [17] experimentally investigated scour around square, roundnosed, and rectangular pier founded in cohesive bed with clay content $C=0.35,0.5,0.7,0.85$, and 1 . Their results were then compared with the result of circular pier of Debnath and Chaudhuri $[15,16]$. They have found that the order of magnitude of maximum scour depth follows as

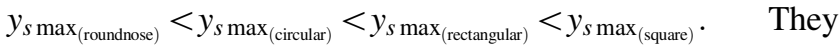
observed a similar order of magnitude for turbulent shear stress also.

\subsection{Parameter characterising the bed material}

In non-cohesive sediment, erosion depends on factors such as grain size distribution, median size $\left(d_{50}\right)$, sediment fall velocity and mass density. Laursen [48] found that under clear-water condition, maximum scour depth is affected by bed sediment size; however, live-bed scour is independent of sediment size. Again, Ettema [49] under clear-water condition and Cheiw [50] under live-bed condition added that the equilibrium scour depth is unaffected by sediment size if $\hat{d}\left(=\frac{b}{d_{50}}\right)>50$; and scour depth decreases if $\frac{b}{d_{50}}<20$ to 25 . Considering identical flow characteristics, Nicollet and Ramette [51] and Dietz [52] conducted experiments at various bed densities and concluded that the scour depth increases with decreasing bed density. Raudkivi and Ettema [7] relates the equilibrium scour depth with median size of the bed particle relative to pier size, depth of flow relative to both median size and pier size, and particle size distribution of the bed material. They found that apart from ripple-forming sediment with sediment gradation $\sigma_{g}\left(=\frac{d_{84}}{d_{16}}\right)<1.5$, the maximum scour depth decreases with the increase in $\sigma_{g}$.

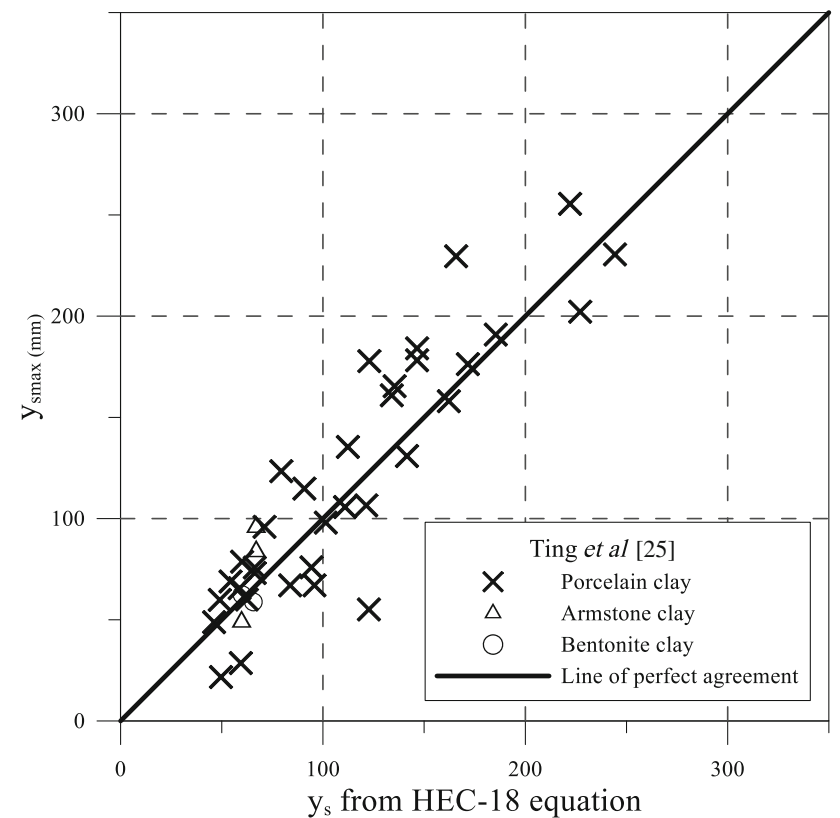

Figure 8. Comparison of maximum scour depth in clay and sand (after Ting et al [25]).

Different from that of non-cohesive soil, erosion of clayey bed depends on \% contents of clay, bed shear strength, initial water content and compaction. Namjoshi [37] conducted experiments in cohesive soil and found that the maximum scour depth does not exceed 1.5 times of pier diameter. Experimental results of Molinas and Hosny [21] show that with the increase in clay content up to $30 \%$ in a mixture of cohesive soils, the scour depth reduces by up to $40 \%$. Beyond $30 \%$ clay content, pier scour depends on other parameters such as water content, degree of saturation, compaction and bed shear strength. Under different flow condition, they observed a steep scour hole with increase in clay content in sandy soils. In unsaturated clay soil, the scour depth decreases with increase in the degree of compaction. At low degree of compaction under unsaturated condition, they observed the shape of the scour hole to be conical. However, under saturated condition at low water contents and under unsaturated condition at high degree of compaction, the shape of the scour hole is more likely to be cylindrical with steeper side slope. Briaud et al [1, 14] introduced an erosion function apparatus (EFA) to measure scour rate versus applied shear stress and developed a method called SRICOS (Scour Rate in Cohesive Soils). It was developed to predict the depth of scour at a given time. Figure 8 is taken after Ting et al [25], which shows the comparison plot of equilibrium scour depth in clay with that of HEC-18 equation. Briaud et al [1] and Ting et al [25] found that maximum scour depth in clay and in sand is identical. In their studies, they did not relate pier scour to the soil properties. 


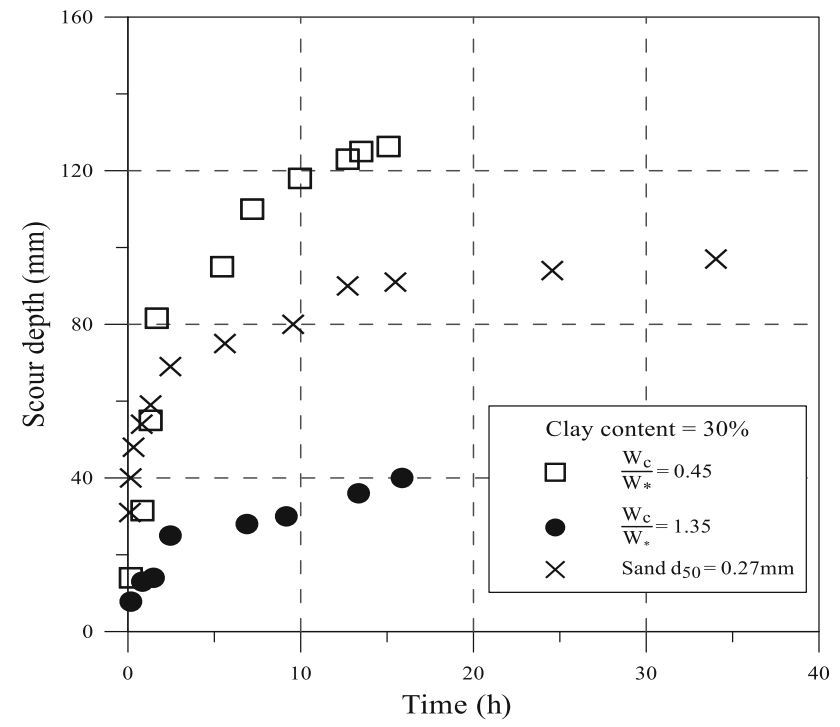

Figure 9. Temporal variation of scour depth around uniform cylindrical bridge pier for $V=0.21-0.48 \mathrm{~m} / \mathrm{s}$ (after Ansari et al [13]).

Based on the initial moisture content of bed sediment, Ansari et al [13] employed kneading or dynamic compaction. Figure 9 shows the temporal development of scour around uniform cylindrical pier taken after Ansari et al [13], and it shows the behaviour of scouring between sand and clay of different antecedent moisture content. Under the similar flow and pier characteristics, Ansari et al [13] observed that the maximum scour depth at pier founded in cohesive bed can be smaller or larger than that in sand and is governed by the antecedent moisture content. They have concluded that the extent of scour hole, location and geometry of scour in cohesive soil are much different from sand. Under unsaturated condition with $C \leq 40 \%$, Ansari et al [13] observed that scouring commences from the pier sides and transmit towards the pier nose, generating deepest scour at the upstream pier nose. However, under saturated condition, maximum scour generates at the pier sides. For clay content $C>50 \%$, scour depth is maximum at the pier sides with negligible scour occurring at the pier nose.

Li et al [19] conducted six flume experiments around constant diameter $(160 \mathrm{~mm})$ circular pier to study the local scour under different bedding condition. They predicted the ultimate scour depth at pier and observed the magnitude of scour depth in decreasing order as clay over sand $>$ sand $>$ clay $>$ sand over clay. According to Rambabu et al [23], the ultimate scour depth is governed by flow velocity, pier size, pier Reynolds number, shear stress, flow Froude number and other soil characteristics. According to them, the resistance to scour around a hydraulic structure embedded in clay is influenced by the strength of the mineral clay, and they have found that with the rise of undrained shear strength the equilibrium scour depth reduces. For $C \geq 20 \%$, Kho et al [18] determined that the maximum scour depth occurs on both the wake and at the sides of the pier; and they have observed that the volume and width of scour hole at the upstream pier nose are inversely proportional to the clay content. Figure 10 shows the variation of non-dimensional scour depth for different percentage of clay reported by Molinas and Hosny [21], Kho et al [18], Debnath and Chaudhuri [16], and Najafzadeh and Barani [22]. The data were chosen for $0.13 \leq F_{r} \leq 0.329$ and $W_{c}<33.55 \%$; however, Kho et al [18] do not mention the value of water content of the bed material. From the figure it is observed that the non-dimensional equilibrium scour depth in the study by Kho et al [18] increases with clay content, which contradicts the trend of other researchers in comparison. The cohesive soil used by Molinas and Hosny [21], Debnath and Chaudhuri [16], and Najafzadeh and Barani [22] is a mixture of sand, clay and silt size particle; however, Kho et al [18] utilised pure clay size particle as cohesive soil.

Debnath and Chaudhuri $[15,16]$ investigated the effect of clay contents, bed shear strength and water content on maximum equilibrium scour depth, equilibrium scour hole geometry, scouring process and temporal variation of scour around cylindrical pier founded in cohesive and non-cohesive mixed bed. They observed that for $W_{c}<24 \%$, non-dimensional maximum scour depth decreases with the increase in clay content, which is supported by the results of Molinas and Hosny [21]. For $W_{c}>27 \%$, the non-dimensional maximum equilibrium scour depth initially reduces with the increase in percentage of clay till clay content reaches nearly 50-70\% and thereafter increased. Based on the experimental results, Debnath and Chaudhuri $[15,16]$ observed that the behaviour of scour hole and the location of maximum scour depth are judged by the combined effect of bed shear strength and the shear stress generated by the approach flow. Figure 11 shows the plot of variation of non-dimensional scour diameter with increase in percentage of clay drawn after Debnath and Chaudhuri $[15,16]$ and Molinas and Hosny [21]. Debnath and Chaudhuri [15] concluded that the sizes of scour hole are significantly smaller with an inverted cone as clay content increase. According to Debnath and Chaudhuri [15-17] cohesive soil scour in different manners such as in the form of lumps, aggregate by aggregate and/or particle by particle. The sizes of the aggregates or lumps that split from the bed sediments are largest for $50 \% \leq C \leq 70 \%$ for constant pier shape and flow condition. Below or above this clay content the sizes of lumps decrease.

Link et al [20] conducted experiments on cohesive bed containing $72 \%$ sand and studied the effect of bed compaction around circular pier. Within the range of compaction energy applied $\left(E=0-2.713 \mathrm{~J} / \mathrm{cm}^{3}\right)$, they observed that the maximum scour depth in cohesive soil ranges from $10 \%$ to $58 \%$ of that occurs in sand with the maximum scour at wake zone. Figure 12 is the plot showing variation of ratio of maximum scour depth in cohesive soil to maximum scour depth in sand $\left(\frac{y_{\text {smax }}}{y_{s m s}}\right)$ with ratio of initial to optimum moulding water content 


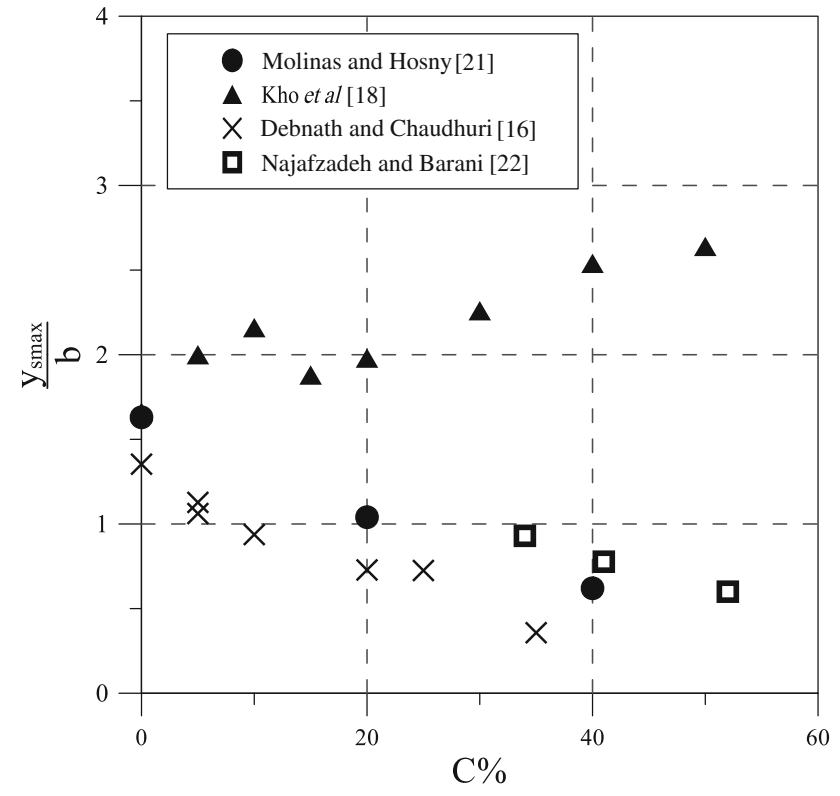

Figure 10. Scour ratio for different clay content with $0.13 \leq F_{r} \leq 0.329$.

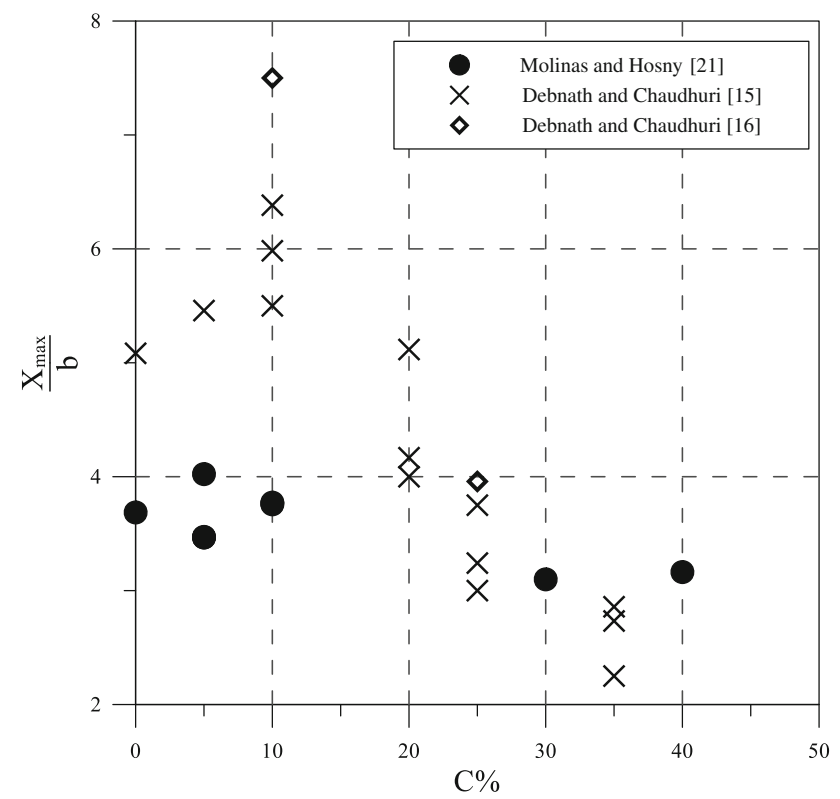

Figure 11. Plot of dimensionless scour diameter as a function of clay content with $V=0.284-0.315 \mathrm{~m} / \mathrm{s}$.

$\hat{W}\left(=\frac{W_{c}}{W_{\text {copt }}}\right)$ at different compaction energy drawn after Link et al [20]. They concluded that for a given compaction energy, the maximum scour depth decrease with increase in $\hat{W}$ up to a value of $\hat{W}\left(=\frac{W_{c}}{W_{\text {copt }}}\right) \leq 2.5$. This is because the individual clay particles formed into aggregated fluffy masses and progressively disseminated with water content. With further increase in water content, when $\hat{W}>2.5$, the maximum scour depth increases with same compaction

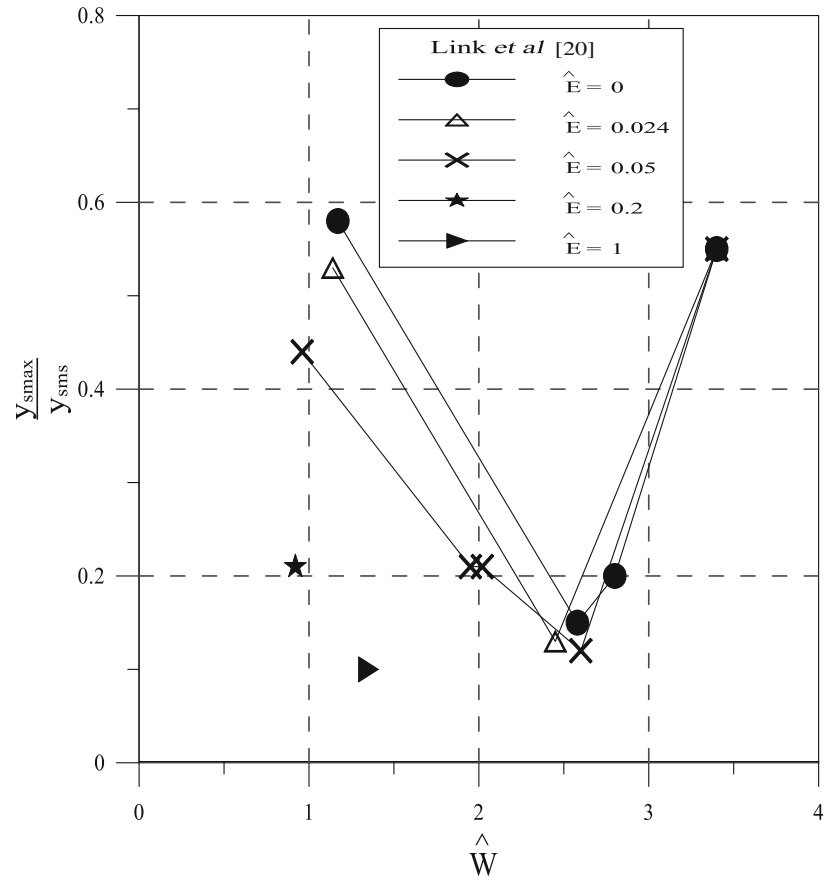

Figure 12. Variation of dimensionless scour depth with dimensionless compaction energy and moulding water content (after Link et al [20]).

energy. They added that at $\hat{W}>2.5$, the sediment matrix act as a fluid mud and then progressively converted into liquid.

Kothyari et al [32] conducted experiments on two types of sediment mixture, namely (a) fine gravel mixed with 20-60\% clay; (b) sand and fine gravel in an equal quantity mixed with $20-60 \%$ clay by weight. They studied the influence of parameters such as unconfined compressive strength, clay content, water content, void ratio and dry density of bed sediment on local scour in wake zone under their experimental condition. For cohesive sediment comprising gravel, Kothyari et al [32] established that unconfined compressive strength and clay fraction are the most significant parameters that affect scour at wake zone of pier generating a decrease in scour depth with increase in both unconfined compressive strength and clay fraction.

Najafzadeh and Barani [22] used a hyperbolic law as was used by Briaud et al [1] and Ting et al [25] and evaluated the ultimate scour depth using the experimental data. They conducted experiments on three types of soil with 52\%, $41 \%, 34 \%$ clay and the initial water content ranging from $10.7 \% \leq W_{c} \leq 33.1 \%$; and investigated the influence of undrain shear strength, flow parameters and initial moisture content on ultimate scour depth. Under unsaturated condition, they also observed that the ultimate scour depth decreases with the increase in undrain shear strength and clay percent; and increases with initial water content. According to Debnath and Chaudhuri [16], Molinas and Hosny [21] and Najafzadeh and Barani [22], the ultimate 


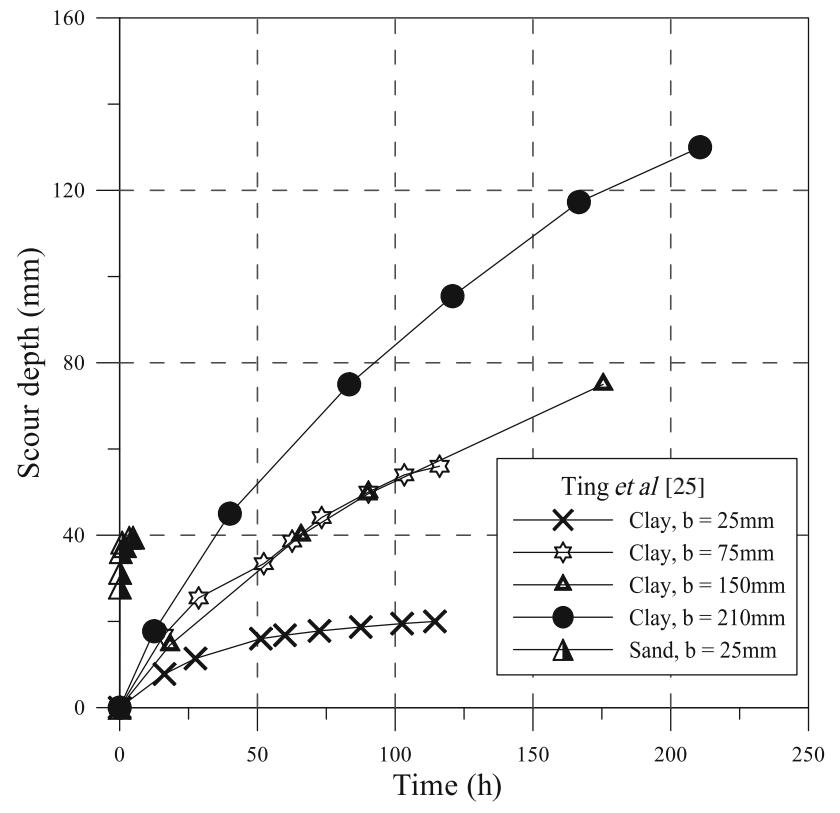

Figure 13. Temporal scour depth for different pier diameter with $V=0.21-0.48 \mathrm{~m} / \mathrm{s}$ (after Ting et al [25]).

scour depth is independent of initial water content for $W_{c}<33.55 \%$. According to Najafzadeh and Barani [22], saturated and unsaturated conditions are significant parameter in predicting scour depth. They used Theil's coefficient test to determine the accuracy of empirical equations and concluded that the empirical equations in non-cohesive soils can be used for predicting scour depth in cohesive soils.

\subsection{Time of scour}

Molinas and Hosny [21] and Debnath and Chaudhuri [15] observed a slower rate of scour as clay content in the bed sediment increases, resulting in much longer time to reach to the stable state of scour. Figure 13 is an illustration plot of the temporal development of scour depth at different pier sizes founded in clay soil, including the scour development in sand under identical flow condition with $V=0.21 \mathrm{~m} / \mathrm{s}$ to $0.48 \mathrm{~m} / \mathrm{s}$. Ting et al [25] and Rambabu et al [23] concluded that clay scour at slower rate than sand, and the time require to reach equilibrium scour depth is greater for larger pier size producing greater scour and vice versa. Rambabu et al [23] observed that at lower flow velocity the steady state is reached earlier than that of higher flow velocity, with the higher flow velocity producing the greater scour.

Rambabu et al [23] and Debnath and Chaudhuri [15-17] observed a higher rate of scour at the initial stage due to the strong feedback effect of flow turbulence. Debnath and Chaudhuri $[15,16]$ observed the erosion of sediment in the form of lump in the first $1 \mathrm{~h}$ of initiation of run having sizes ranges from $2 \mathrm{~mm}$ to $5 \mathrm{~mm}$.
In aggregate-by-aggregate mode of erosion, aggregates of size $1 \mathrm{~mm}$ or lower containing sand size particle within them were transported out of the scour hole as suspended or bed load. In a particle-by-particle mode of erosion, the individual clay particle, sand particle and loosen flocculent material freed themselves from the sediment matrix and continually transported out of the scour hole throughout the entire scouring process. During this mode of erosion, the sediment bed appears to be inactive; however, the scour depth increases gradually.

Kothyari et al [32] observed that for lesser clay content with $C \leq 30 \%$, the scour occur by removal of particles from around the pier while above this clay content scour occur in the form of thin flakes. For clay content $C>40 \%$, and for higher unconfined compressive strength $\left(12.13 \mathrm{kN} / \mathrm{m}^{2}\right.$ to $21.3 \mathrm{kN} / \mathrm{m}^{2}$ ) with the other parameters nearly similar, they observed negligible or no scour at the initial stage in the wake zone. However, after nearly $30 \mathrm{~min}$ of run, erosion starts in the form of chunk thereby abruptly increasing the depth of scour in wake zone.

\section{Estimation of scour depth}

The available equations developed by Molinas and Hosny [21]; Briaud et al [1, 14]; Ting et al [25]; Ansari et al [13], Rambabu et al [23]; Kho et al [18]; Debnath and Chaudhuri [15, 16], Kothyari et al [32]; Najafzadeh and Barani [22] proposed to estimate the maximum scour depth at bridge pier embedded in cohesive bed material are discussed. In addition, the equations adopted by Indian Road Congress (IRC) based on the proposed equation of Lacey [53] are also included.

Molinas and Hosny [21] conducted three sets of experiments to investigate bridge pier scour in a mixture of cohesive and non-cohesive soils and in unsaturated cohesive soils. In the first set, they used a masonry sand of $0.55 \mathrm{~mm}$ mean grain size mixed with $0,5,10,20,30$ and $40 \%$ of cohesive soil as bed materials. They developed a relationship between the upstream side slope of scour hole $(Z)$, and clay content $(C)$ and approximated the diameter of scour hole $(B)$ as follows:

$$
\begin{gathered}
Z=1.422+0.06(\% C) \\
B=2 b+2 Z y_{\text {smax }}
\end{gathered}
$$

They found that the upstream side slope of scour hole steepens with decreasing clay content. A relationship between the maximum scour depth $\left(y_{\text {smax }}\right)$ and scour volume $\left(V_{s}\right)$ in dimensionless form is also developed.

$$
\frac{y_{s \max }}{b}=0.4\left(\frac{V_{s}}{b^{3}}\right)^{0.41}
$$

Keeping other soil properties such as compaction energy, initial water content and shear strength constant, they 
proposed an expression for pier scour in clayey-sand mixture with up to $31 \%$ silt-clay contents by dry weight. The proposed equation is as follows:

$$
\frac{y_{s \max }}{b}=18.92\left(\frac{F_{r}^{2.08}}{(1+C)^{1.88}}\right)
$$

where $C$ is the fraction of cohesive soil finer than sand up to $31 \%$; Froude number ranging from 0.18 to 0.33 .

In the second set, they investigated the behaviour of pier scour in unsaturated clay soil at various degrees of compaction and derived an empirical equation to estimate the maximum scour depth under unsaturated condition in terms of Froude number, degree of compaction (Сотр.), initial water content and vane shear strength $\left(\tau_{s}\right)$.

$$
\frac{y_{\text {smax }}}{b}=2.71\left(W_{c}\right)^{-0.36} F_{r}^{1.92}\left(\frac{\tau_{s}}{\rho V^{2}}\right)^{0.023}(\text { comp. })^{-1.62}
$$

where $\rho$ is the fluid density.

Using the results of the third set of experiments, they studied the effect of initial water content and Froude number and developed a scour depth relation under saturated condition. The equation is as follows:

$$
\frac{y_{\text {smax }}}{b}=5.48\left(W_{c}\right)^{1.14}\left(F_{r}-F_{c}\right)^{0.6}
$$

where $F_{c}=\frac{0.035}{W_{c}^{2}}$ and $y_{s \max }=0$ for $F_{r} \leq F_{c}$

Finally, they have developed a generalised equation for both saturated and unsaturated conditions using the data of second and third sets of experiments. The generalised equation is given as follows.

$$
\frac{y_{s \max }}{b}=0.9\left(W_{c}\right)^{-2 / 3} F_{r}^{3 / 2}(\text { comp. })^{-2}
$$

Molinas and Hosny [21] did not try to relate the relation of scour depth with model geometry, size and gradations of sediment used in the mixture and are not envisioned for general application too. They only clarify the variability of pier scour with cohesive properties.

Briaud et al [1] proposed a method called SRICOS as mentioned in the previous section. SRICOS is a step-bystep methodology to predict the scour depth $\left(y_{s t}\right)$ versus time $(t)$ around a circular bridge pier founded in clayey soil. The steps include: (i) collecting the soil sample from bridge site; (ii) developing a curve between applied shear stress and erosion rate using erosion function apparatus; (iii) predicting maximum shear stress $\left(\tau_{\max }\right)$ around the pier before the start of the scour due to approach flow velocity; (iv) determining the initial scour rate $\left(y_{s i}\right)$ corresponding to maximum shear stress $\left(\tau_{\max }\right)$ from shear stress versus erosion rate curve; (v) determining the maximum scour depth $\left(y_{s \max }\right)$ using Eq. (9); (vi) using the initial scour rate and maximum scour depth, determine the time evaluation of scour depth. They obtained $\tau_{\max }$ by performing a series of numerical simulation for various pier diameters and flow velocities on flat-bed condition using a computational fluid dynamic model. Utilising the data obtained from the simulation, they developed an equation to predict $\tau_{\max }$ and is as follows:

$$
\tau_{\max }=0.094 \rho V^{2}\left(\frac{1}{\log R_{p}}-\frac{1}{10}\right)
$$

where $R_{p}(=V b / v)$ is the pier Reynolds number, $v$ is the kinematic viscosity of water $=10^{-6} \mathrm{~m}^{2} / \mathrm{s}$ at $20^{\circ} \mathrm{C}$.

Based on the experimental results conducted on clayey soil at circular pier, an empirical equation was proposed to find the value of maximum equilibrium scour depth $\left(y_{s \max }\right)$ and is given as follows:

$$
y_{\text {smax }}=0.18 R_{p}^{0.635}
$$

Further, they proposed a hyperbolic function in terms of $y_{s i}$ and $y_{s \max }$ to predict the time variation of scour depth. The proposed relation is as follows:

$$
y_{s t}=\frac{t}{\frac{1}{y_{s i}}+\frac{t}{y_{\text {smax }}}}
$$

This method is limited for circular pier, deep-water condition (approach flow depth to pier diameter ratio more than 2), uniform soil formation and constant velocity hydrograph. However, the natural river flow is unsteady and the riverbed consists of different soil layers and gradations. Thus, the proposed equation may not be applicable to all conditions.

Ting et al [25] used the hyperbolic model (Eq. 10) in their study. They obtained the value of $y_{s i}$ and $y_{s \operatorname{smax}}$ using the Levenberg-Marquardt method [54]. They proposed an empirical equation for predicting the equilibrium scour depth in terms of pier Reynolds number at circular pier founded on clayey bed. The proposed equation is as follows:

$$
y_{\text {smax }}=0.12 R_{p}^{0.682}
$$

The limitation of Eq. (9) and Eq. (11) is that they did not include sediment properties. Briaud et al [1] and Ting et al [25] observed that the effect of flow depth and Froude number were not apparent under their ranges of study. The range of Froude number used by Ting et al [25] was very low, ranging from 0.1 to 0.42 . The objectives of Ting et al [25] were to understand the physical process of scouring in clayey soil and to develop a theoretical model for predicting temporal depth of scour in clayey soil.

Ansari et al [13] studied the scouring process and temporal development of scour depth at a circular bridge pier founded in clay-sand mixture having percentage of illite clay varying from $5 \%$ to $60 \%$. They conducted experiments under clear-water condition on non-plastic $(P I<0)$ and 
plastic sediments $(P I>0)$. Considering the horseshoe vortex to be the prime agent causing scour, they developed a step-by-step procedure for calculating the temporal deviation of scour depth in cohesive bed. Again, they proposed empirical equations for the approximation of the maximum scour depth at bridge pier in cohesive sediments. The equations are as follows:

$$
\begin{gathered}
\frac{y_{s \max }}{y_{s m s}}=1.51\left(\frac{W_{c}}{W_{*}}\right)^{0.35}\left(\frac{C_{*}}{\phi_{*}}\right)^{0.2} \text { for } P I=0 \\
\frac{y_{s \max }}{y_{s m s}}=\frac{6.02-10.82\left(\frac{W_{c}}{W_{*}}\right)+5.41\left(\frac{W_{c}}{W_{*}}\right)^{2}}{\left(\frac{C_{*}}{\phi_{*}}\right)^{0.2}} \text { for } P I \geq 4
\end{gathered}
$$

where $W_{*}$ is the moisture content required to saturate the soil sample, which is equal to liquid limit for plastic sediment; $C_{*}$ and $\phi_{*}$ are the indicator of cohesiveness of clay, silt and sand mixture given by

$$
\begin{gathered}
C_{*}=\frac{C C_{u}}{\Delta \gamma_{s} d_{a}} \\
\phi_{*}=\frac{C \tan \phi_{c}+(1-C) \tan \phi_{s}}{\tan \phi_{s}}
\end{gathered}
$$

In the aforementioned equations, $C_{u}$ is the cohesion, $\Delta \gamma_{s}$ is the difference in specific weight of sediment and water, $d_{a}$ is the arithmetic mean size of sediment mixture, $\phi_{c}$ and $\phi_{s}$ are the internal friction for cohesive sediments and sand, respectively. Ansari et al [13] assumed the cohesive sediment to be eroded in the form of aggregates in the model analysis to develop the temporal scour depth. However, the experimental results of Ansari et al [13] and Kothyari et al [32] show that the cohesive sediment of various clay content, shear strength and water content get eroded in the form of cluster of sediment particles called lumps or flakes.

Using the hyperbolic model as was used by Briaud et al [1] and Ting et al [25], Rambabu et al [23] evaluated the ultimate depth of scour at piles in cohesive soil from data obtained from short-duration test. Rambabu et al [23] developed an empirical equation relating the ultimate depth of scour to pier diameter, flow velocity, model Reynolds number, bed shear resistance and Froude number. The empirical equation is as follows.

$$
\frac{y_{s \max }}{b}=\left(\frac{V}{\sqrt{g h}}\right)^{0.641}\left(\frac{V b}{v}\right)^{0.64}\left(\frac{\tau_{s}}{\gamma_{s} h}\right)^{-0.976}
$$

where $\gamma_{s}$ is the unit weight of bed sediments. They suggested the aforementioned equation for prediction of ultimate scour depth for the range of $0.08<F_{r}<0.18$, $10,000<R_{p}<36,000$ and $0.026<\tau_{c} / \tau_{s}<0.104$; where $\tau_{c}$ is the critical shear stress.

Briaud et al [55] extended the SRICOS-EFA method to include layered soil under multiflood hydrograph; it is called the Extended-SRICOS or E-SRICOS. It was again upgraded by Briaud et al [14] to include the shallow water depth effect, attack-angle effect on rectangular shape pier, effect of pier shape on rectangular pier for different aspect ratio, and lastly the pier spacing effect between piers positioned in a row perpendicular to the approach flow. They have modified the equation of maximum shear stress and maximum scour depth for the cylindrical pier in deep water with correction factor as follows:

$$
\begin{gathered}
\tau_{\max }=k_{w} k_{s p} k_{s h} k_{a} \times 0.094 \rho V^{2}\left[\frac{1}{\log \frac{V b^{\prime}}{v}}-\frac{1}{10}\right] \\
y_{s \max }=k_{w} k_{s p} k_{s h}\left(0.18 R_{p}^{0.635}\right)
\end{gathered}
$$

where $b^{\prime}$ is the projected width of the pier perpendicular to the flow; $k_{w}, k_{s p}$ and $k_{a}$ are the correction factors for shallow water effect, pier spacing effect and effect of attack angle, respectively. Expressions for the correction factors on maximum scour depth are as follows:

$$
\begin{aligned}
& k_{w}= \begin{cases}0.85\left(\frac{h}{b^{\prime}}\right)^{0.34} & \text { for } \frac{h}{b^{\prime}}<1.62 \\
1 & \text { for } \frac{h}{b^{\prime}}>1.62\end{cases} \\
& k_{s p}=\frac{W_{\prime}}{W_{1}-n b^{\prime}}
\end{aligned}
$$

where $W^{\prime}$ is the width of the channel without the pier, $n$ is the number of pier.

$$
k_{s h}=\left\{\begin{array}{lc}
1.1 \frac{l}{b}>1 & \text { for rectangular pier } \\
1 \quad & \text { for circular pier }
\end{array}\right.
$$

Expressions for the effect of correction factors on maximum shear stress are as follows:

$$
\begin{aligned}
& k_{w}=1+16 e^{-\frac{4 h}{b^{\prime}} ; k_{s p}}=1+5 e^{-1.1 \frac{s}{b^{\prime}}} ; k_{s h}=1.15+7 e^{-4 \frac{L}{b}} \\
& k_{a}=1+1.5\left(\frac{\alpha}{90}\right)^{0.57} .
\end{aligned}
$$

Briaud et al [14] suggested a safety factor of 1.5 for design purpose in the SRICOS-EFA method. Although the proposed method is applicable to various type of soil condition, it is yet to be verified with the field data. Moreover, the soil sample has to be tested to the EFA developed by them.

Kho et al [18] conducted laboratory experiment under live-bed scour condition with $0.21 \leq F_{r} \leq 0.43$. They used three types of soils, namely, synthetic Supreme kaoline (made up of clay size particle $\left(d_{50}<0.002 \mathrm{~mm}\right)$, Grade E kaoline (made up of silt size particles $(0.002 \mathrm{~mm}<$ $\left.d_{50}<0.06 \mathrm{~mm}\right)$ and very fine silica sand $\left(d_{50}\right.$ of $\left.0.14 \mathrm{~mm}\right)$. Based on the experimental results, they developed an 
empirical equation to predict the equilibrium scour depth and is given as follows:

$$
y_{\text {smax }}=0.0044 R_{p}^{1.0234}(1+C)^{0.5} .
$$

They also proposed a regression equation for side slope of scour hole $Z$ as

$$
Z=0.3205 C+30.84 \text {. }
$$

Debnath and Chaudhuri [15] carried out 56 experimental run to investigate local scour at circular bridge pier embedded in clay-sand mixed sediment beds that comprised two different sand size $\left(d_{50}=0.182 \mathrm{~mm}\right.$ and $\left.0.44 \mathrm{~mm}\right)$. They developed an empirical equation to estimate the non-dimensional maximum scour depth and scour hole diameter for piers founded in clay-sand mixture in terms of pier Froude number, water content, clay content, and bed shear strength having $C<0.4, W_{c}<0.4$ and $0.78 \leq \hat{V}\left(=\frac{V}{V_{c s}}\right) \leq 1.65$. The proposed equations are as follows:

$$
\begin{aligned}
& \hat{y}_{s \max }=8.2 F_{p}^{0.79} C^{-0.28} W_{c}^{0.15} \hat{\tau}_{s}^{-0.38} \\
& \hat{X}_{\max }=22.77 F_{p}^{0.57} C^{-0.19} W_{c}^{0.2} \hat{\tau}_{s}^{-0.26}
\end{aligned}
$$

where $\hat{y}_{s \max }\left(=\frac{y_{\text {smax }}}{b}\right)$ and $\hat{X}_{\max }\left(=\frac{X_{\max }}{b}\right)$ are non-dimensional maximum equilibrium scour depth and scour hole diameter, respectively. $\hat{\tau}_{s}\left(=\frac{\tau_{s}}{\rho V^{2}}\right)$ is non-dimensional bed shear strength and $V_{c s}$ is the critical threshold velocity for sand used in clay-sand mixture. The range of flow Froude number they considered is $0.13<F_{r}<0.282$.

Later on, Debnath and Chaudhuri [16] extended their finding by conducting 71 laboratory flume experiments on circular piers on clay-sand mixed sediment beds with $20 \% \leq C \leq 100 \%, 20 \% \leq W_{c} \leq 45.92 \%, 0.459<F_{p}<0.754$ and $0.268<F_{r}<0.44$. The cohesive materials used were both kaolinite clay and muddy sediments from the lower course of river Ganga in India $\left(d_{50}\right.$ of sand $\left.=0.182 \mathrm{~mm}\right)$. Based on the experimental data regression equations to estimate the dimensionless maximum scour depth at pier founded in claysand mixed bed was proposed and are as follows:

$$
\begin{aligned}
& \hat{y}_{s \max }=2.05 F_{p}^{1.72} C^{-1.29} \hat{\tau}_{s}^{-0.37} \\
& \text { for } W_{c}=20-23.22 \% \text { and } 20 \% \leq C \leq 85 \% \\
& \hat{y}_{s \max }=3.64 F_{p}^{0.22} C^{-1.01} \hat{\tau}_{s}^{-0.69} \\
& \text { for } W_{c}=27.95-33.55 \% \text { and } 20 \% \leq C \leq 50 \% \\
& \hat{y}_{\text {smax }}=20.52 F_{p}^{1.28} C^{0.19} \hat{\tau}_{s}^{-0.89} \\
& \text { for } W_{c}=27.95-33.55 \% \text { and } 50 \% \leq C \leq 100 \% \\
& \hat{y}_{s \max }=3.32 F_{p}^{0.72} C^{-0.62} W_{c}^{0.36} \hat{\tau}_{s}^{-0.29} \\
& \text { for } W_{c}=33.6-45.92 \% \text { and } 20 \% \leq C \leq 70 \%
\end{aligned}
$$

$$
\begin{aligned}
& \hat{y}_{s \max }=8 F_{p}^{0.61} C^{-0.58} W_{c}^{1.24} \hat{\tau}_{s}^{-0.19} \\
& \text { for } W_{c}=33.6-45.92 \% \text { and } 70 \% \leq C \leq 100 \% .
\end{aligned}
$$

Equations of Debnath and Chaudhuri [15, 16] showed that $\hat{y}_{\max }$ depends on $C, \mathrm{~W}_{c}, \hat{\tau}_{s}$; however, shear strength of the soil is governed by the compositions of cohesive soil, which can be revealed by the physical parameters such as clay content, plasticity index, plastic and liquid limit, surface area; texture or structural feature.

Kothyari et al [32] proposed a relationship to estimate the depth of scour in the wake zone of piers in clay-gravel and clay-sand-gravel sediment mixture and are, respectively, given as follows.

$$
\begin{aligned}
& \frac{y_{s c w}}{y_{s s}}=\left[(1+C)^{5.64}\right]\left[\left(1+U C S^{*}\right)^{0.42}\left(t_{*}^{-0.24}\right)\right]^{-1} \\
& \frac{y_{s c w}}{y_{s s}}=\left[(1+C)^{5.98}\right]\left[\left(1+U C S^{*}\right)^{0.69}\left(t_{*}^{-0.42}\right)\right]^{-1}
\end{aligned}
$$

where $y_{s c w}$ is the maximum depth of scour in wake zone in cohesive sediment and $y_{s s}$ is the maximum scour depth in cohesionless sediment. $t_{*}=$ dimensionless time defined as $t_{*}\left(=t \frac{V_{*}}{d_{a}}\right), \quad V_{*}$ is shear velocity; $U C S^{*}\left(=\frac{U C S}{\Delta \gamma_{s} d_{a}}\right)$ is the dimensionless unconfined compressive strength of cohesive sediment bed; UCS is unconfined compressive strength of cohesive sediment bed. Analysing the experimental data they found that unconfined compressive strength of the clay-gravel and clay-sand-gravel is not dependent on the clay content of the sediment mixture.

Najafzadeh and Barani [22] investigated the effect of flow velocity, flow depth, initial moisture content, undrained shear strength and clay percent on scour around bridge pier entrenched in cohesive soil. They performed the experiment with a pier of $0.1 \mathrm{~m}$ in diameter with the flow Froude number $\left(0.067<F_{r}<0.131\right)$. Najafzadeh and Barani [22] utilised the hyperbolic model as was done by Rambabu et al [23] and extrapolated the ultimate scour depth at pier in cohesive soil. They developed an empirical equation for ultimate scour depth in terms of effective parameter and is given as follows.

$$
\frac{y_{s \max }}{h}=5565.05\left(\frac{\tau_{s}}{\gamma_{s} h}\right)^{0.83} C^{-2.179}\left(\frac{V}{\sqrt{g h}}\right)^{2.306}
$$

Najafzadeh and Barani [22] eliminated the effect of $W_{c}$ as they found a low correlation coefficient of 0.76 using a plot of $\frac{y_{\operatorname{smax}}}{h}$ with $W_{c}$. Equation (30) was derived using the experimental data conducted on saturated soft clay soil having consistency index $0.19,0.23$ and 0.3. Equation (30) did not include the effect of obstruction size, which is a fundamental parameter in local scour. The ranges of approach flow depth to pier diameter kept by them was $3 \leq \frac{h}{b} \leq 4.5$, which indicates that the maximum scour depth is independent of approach flow depth [14]; however, they 
considered flow depth as the effective parameter rather than pier diameter in their equation.

Lacey [53] analysed data from stable irrigation channels flowing through loose sandy material in the Indo-Gangetic plain and defined regime width $W$ and normal regime scour depth below the design flood level $R$ by the following two equations.

$$
\begin{gathered}
W=4.75 \sqrt{Q} \\
R=0.47\left(Q_{/ f}\right)^{1 / 3}
\end{gathered}
$$

Here, $Q$ is the design flood discharge in $\left(\mathrm{m}^{3} / \mathrm{s}\right)$ and $f$ is the Lacey's silt factor.

$$
f=1.76 \sqrt{d_{50}}
$$

The aforementioned regime scour depth is applicable when the river width is equal to the regime width $W$. In case the width of the river is less than the regime width, the normal scour depth $R^{*}$ is calculated by the following equation

$$
R^{*}=1.34\left(q^{2} / f\right)^{1 / 3}
$$

Here, $q$ is the discharge intensity per unit width of stream $=Q / B^{\prime}$ where $B^{\prime}$ is the actual river width.

The Indian Railway Standard [56], IRC:5 [57] and IRC:78 [58] recommended to calculate mean scour depth below the highest flood level for natural channel flowing in alluvium using Lacey's equation (34). For design purpose, it is recommended to consider the maximum scour depth $y_{\text {sms }}$ around bridge pier as

$$
y_{\text {sms }}=2 R^{*} \text {. }
$$

Clayey bed having weighted diameter less than 0.04 offers more resistance to scour than sand, IRC:78 [58] recommended the following theoretical calculation for silt factor $f$ :

In case of soil having $\phi_{c}$ (angle of internal friction) $<15^{\circ}$ and $C_{u}$ (cohesion) $>0.2 \mathrm{~kg} / \mathrm{cm}^{2}$,

$$
f=F\left(1+\sqrt{C_{u}}\right) \text { where } C_{u} \text { is in } \mathrm{kg} / \mathrm{cm}^{2}
$$

Here,

$$
F= \begin{cases}1.50 & \text { for } 10^{\circ}<\phi_{c}<15^{\circ} \\ 1.75 & \text { for } 5^{\circ}<\phi_{c}<10^{\circ} \\ 2.00 & \text { for } \phi_{c}<5^{\circ}\end{cases}
$$

In case of soil having $\phi_{c}>15^{\circ}$ will be treated as sandy soil even if $C_{u}>0.2 \mathrm{~kg} / \mathrm{cm}^{2}$ and $f$ will be calculated using Eq. (33).

Although provision for estimation of scour depth in cohesive soil is provided in IRC:78 [58] for soil having $C_{u}>0.2 \mathrm{~kg} / \mathrm{cm}^{2}$; but there is no provision for calculating the scour depth in cohesive soil where $C_{u}<0.2 \mathrm{~kg} / \mathrm{cm}^{2}$. The scour depth calculated using Eq. (37) produces less scour depth than that in coarse sand, which is not true for all types of cohesive soil. Again, if the width of the river is more than the regime width, Eq. (32) may not produce any scour depth; however, there will always be local scour around the bridge pier. In summary, IRC recommendations based on Lacey's regime theory did not consider the details of obstruction size and shape, bed material properties and flow conditions, whereas scour around obstructions such as bridge pier, bridge abutment, and guide banks depends on the above parameters.

\section{Numerical examples for estimation of design scour depth}

Comparison of the estimated design scour depth at a circular bridge pier using the aforementioned equations, those given by Molinas and Hosny [21]; Ting et al [25]; Rambabu et al [23]; Briaud et al [14]; Kho et al [18]; Debnath and Chaudhuri [16]; Najafzadeh and Barani [22] is shown in table 4. In addition, the evaluated value of the so-called CSU or HEC-18 equation (Arneson et al [59] recommended by FHWA for estimating equilibrium scour depth at simpler piers in noncohesive bed is also presented in table 4 .

The HEC-18 equation is as follows:

$$
\frac{y_{s m s}}{b}=2.0 k_{s h} k_{a} k_{b}\left(\frac{h}{b}\right)^{0.35} F_{r}^{0.43}
$$

\begin{tabular}{|c|c|c|}
\hline \multirow[b]{2}{*}{ Investigators } & \multicolumn{2}{|c|}{$\begin{array}{l}\text { Equilibrium scour depth, } y_{\text {smax }}(\mathrm{m}) \text { or } \\
y_{\text {sms }}(\mathrm{m})\end{array}$} \\
\hline & $\begin{array}{l}\text { Laboratory } \\
\text { condition } \\
\text { Example } 1\end{array}$ & $\begin{array}{c}\text { Field } \\
\text { condition } \\
\text { Example } 2\end{array}$ \\
\hline Molinas and Hosny [21] & 0.25 & 0.41 \\
\hline Ting et al [25] & 0.26 & 3.14 \\
\hline Rambabu et al [23] & 37.81 & $102,776.80$ \\
\hline Briaud et al [14] & 0.26 & 2.57 \\
\hline Kho et al $[18]$ & 0.62 & 25.11 \\
\hline $\begin{array}{l}\text { Debnath and Chaudhuri } \\
\text { [16] }\end{array}$ & 0.18 & 2.25 \\
\hline HEC-18 equation & 0.21 & 3.32 \\
\hline $\begin{array}{l}\text { Najafzadeh and Barani } \\
\text { [22] }\end{array}$ & 1715.91 & 19.28 \\
\hline
\end{tabular}

here $k_{s h}=1$ for circular pier

$k_{a}=1$ for $0^{\circ}$ flow attack angle

$k_{b}=1.1$ for clear water with flat bed.

Example 1: laboratory condition

Table 4. Scour depth estimated using equations of different investigators. 
- Model pier diameter, $b=0.08 \mathrm{~m}$

- Approaching flow depth, $h=0.20 \mathrm{~m}$

- Relative density or specific gravity of sediment particle $=2.60$

- Mean approach velocity of flow, $V=1.0 \mathrm{~m} / \mathrm{s}$

- Cohesive material $C \%=80$

- Bed shear strength, $\tau_{s}=1.22 \times 10^{4} \mathrm{~N} / \mathrm{m}^{2}$

- Antecedent moisture content, $W_{c} \%=45.0$

- Degree of compaction $\%=65.3$.

Example 2: Field condition

- Bridge pier diameter, $b=3.0 \mathrm{~m}$

- Approaching flow depth, $h=4.0 \mathrm{~m}$

- Relative density or specific gravity of sediment particle $=2.60$

- Mean approach velocity of flow, $V=1.0 \mathrm{~m} / \mathrm{s}$

- Cohesive material $C \%=80$

- Bed shear strength, $\tau_{s}=1.22 \times 10^{4} \mathrm{~N} / \mathrm{m}^{2}$

- Antecedent moisture content, $W_{c} \%=45.0$

- Degree of compaction $\%=65.3$.

The calculated values of equilibrium scour depths, both for laboratory and for field condition, are shown in table 4. It is observed from table 4 that the calculated values of equilibrium scour depth, $y_{s \operatorname{smax}}$ for Rambabu et al [23] and Najafzadeh and Barani [22] are quite large for both examples 1 and 2 . The scour depth predicted using the equation of Najafzadeh and Barani [22] is not consistent with either the laboratory or the field conditions. The reason for the unexpected result is not clear. Comparison of estimated value of $y_{s \max }$ for cohesive bed calculated using Ting et al [25]; Briaud et al [14]; Debnath and Chaudhuri [16] closely agrees with that of HEC-18 (2012) equation for sand bed. Calculated values of scour depth using the equation given by Kho et al [18] is also on much higher side. Generalised equation of Molinas and Hosny [21] under predicts the scour depth under field conditions. The large discrepancy in the calculated values among the empirical equations may be because of the fact that most of the above equations were derived by regression analysis of laboratory experimental data. The experimental ranges of different parameter were small and even all the parameters were not included. Each of the equation may be valid for the conditions under which the tests were conducted. Thus, all the equations are not applicable for all conditions as observed from table 4.

\section{Conclusion}

Extensive studies have been carried out on local scour at different pier embedded in non-cohesive soil. However, a few researchers have investigated on local scour around pier embedded in cohesive soil. Some investigators related the scour depths with the flow parameters and pier conditions without incorporating the properties of the bed materials $[1,14,25]$, while some others $[13,15-17,20,21]$ related the scour depths with cohesive soil properties. Scour depths predicted using the former appear to be close to the values predicted using equations for non-cohesive soil, while scour depths predicted using latter sets of equations give lesser depths as percentage of clay increases. Moreover, most of the studies on local scour in cohesive soils are restricted to uniform pier. Comparison of scour depths calculated using some of the recently published equations was made considering a laboratory and a field condition. The calculated values show large discrepancy among the empirical equations. Further, IRC recommendation for calculation of scour depth around bridge pier and other obstructions is based on Lacey's equations incorporating some safety factor. Scour around obstructions depends on parameters such as obstruction shape and size, soil properties and flow properties, which were not considered in Lacey's equation. Therefore, IRC recommendation should also be reviewed for both cohesive and non-cohesive soil. Some of the studies have shown that the scour in cohesive soil can be less, equal or even more than that in non-cohesive soil depending on soil properties under similar flow and pier condition. Hence, from the available literature, it is observed that the exact scour mechanism and effect of different parameter on scour depth around bridge pier embedded in cohesive soil are yet to be fully understood or explored and generalised equation incorporating all the parameters is to be developed.

\section{Acknowledgements}

Support provided by MHRD and National Institute of Technology, Silchar, India, for the research is appreciated.

\section{List of symbols}

$b \quad$ pier width or pier diameter

$B \quad$ diameter of scour hole

$b^{\prime} \quad$ projected width of pier perpendicular to the flow

$b^{*} \quad$ foundation diameter of circular non-dimensional pier

$C \quad$ clay content

CEC cation-exchange capacity

Comp. degree of compaction of clayey soil

$C_{u} \quad$ cohesion

$d_{a} \quad$ arithmetic mean size of the sediment mixture

$d_{50} \quad$ mean particle size

$d_{84} \quad$ sediment size for which $84 \%$ of bed material is finer

$d_{16} \quad$ sediment size for which $16 \%$ of bed material is finer

$\hat{d} \quad$ ratio of pier diameter to median sediment size

E compaction energy

$F_{r} \quad$ flow Froude number

$F_{p} \quad$ pier Froude number 
$U C S^{*}$ dimensionless unconfined compressive strength of cohesive sediment bed

UCS unconfined compressive strength of cohesive sediment bed

$V \quad$ approaching flow velocity

$V_{a} \quad$ armour velocity

$V_{s} \quad$ scour volume

$V_{c s} \quad$ critical threshold velocity for sand used in claysand mixture

$V_{c} \quad$ critical mean velocity at the threshold condition

$V_{*} \quad$ shear velocity

$V_{* c} \quad$ critical shear velocity

$\hat{V} \quad$ non-dimensional approach velocity

$W_{*} \quad$ antecedent moisture content required to saturate the soil sample

$W_{c} \quad$ initial moisture content (\%)

$W_{\text {copt }} \quad$ proctor optimum water content

$\hat{W} \quad$ non-dimensional water content

$X_{\max } \quad$ maximum equilibrium scour hole diameter

$\hat{X}_{\max } \quad$ non-dimensional maximum equilibrium scour hole diameter

$Y \quad$ depth from bed level to the top of the foundation

$y_{\text {smax }} \quad$ maximum scour depth

$y_{\text {sms }}$

$y_{s c w}$

$y_{s s}$

$y_{s t}$

$y_{s m x}$

$\hat{y}_{\text {smax }}$

Z

$\alpha$

$\Delta \gamma_{s}$

$\gamma_{s}$

$\gamma_{w}$

$\rho$

$\phi_{c}$

$\theta$

$\phi_{s}$

$\sigma_{g}$ $\tau_{s}$

$\tau_{c} \quad$ critical shear stress of bed sediment at threshold condition

$\tau_{c s} \quad$ shield's critical shear stress for cohesionless sediments

$\tau_{\max } \quad$ maximum shear stress

$\hat{\tau}_{s} \quad$ non-dimensional bed shears strength

\section{References}

[1] Briaud J L, Ting F C K, Chen H C, Gudavalli R, Perugu S and Wei G 1999 SRICOS: prediction of scour rate in cohesive soils at Bridge Piers. J. Geotech. Geoenviron. Eng. 125(4): 237-246

[2] Shirole A M and Holt R C 1991 Planning for comprehensive bridge safety assurance program. Transportation Research Record No.1290, Third Bridge Engineering Conference 1: 39-50

[3] Dey S, Bose S K and Sastry G L N 1995 Clear water scour at Circular pier: a model. J. Hydraul. Eng. 121(12): 869-876

[4] Laursen E M and Toch A 1953 A generalized model study of scour around bridge piers and abutment. In: Proceedings of IAHR International Hydraulics Conference, Minnesota, pp. 123-131

[5] Melville B M and Cheiw Y M 1999 Time scale for local scour at bridge piers. J. Hydraul. Eng. 125(1): 59-65

[6] Melville B W 1997 Pier and abutment scour: integrated approach. J. Hydraul. Eng. 123(2): 125-136

[7] Raudkivi A J and Ettema R 1983 Clear-water scour at cylindrical piers. J. Hydraul. Eng. 109(3): 338-350

[8] Sheppard D M and Miller W 2006 Live bed local pier scour experiments. J. Hydraul. Eng. 132(7): 635-642

[9] Kumar A and Kothyari U C 2012 Three-dimensional flow characteristics within the scour hole around circular uniform and compound piers. J. Hydraul. Eng. 138(5): 420-429

[10] Sheppard D M, Melville B and Demir H 2013 Evaluation of existing equations for local scour at bridge pier. J. Hydraul. Eng. 140(1): 14-32

[11] Kothyari U C 2007 Indian practice on estimation of scour around bridge piers-a comment. Sadhana 32(3): 187-197

[12] Kothyari U C and Fish 2008 Bridge scour: status and research challenges. J. Hydraul. Eng. 14(1): 1-27

[13] Ansari S A, Kothyari U C and Ranga Raju K G 2002 Influence of cohesion on scour around bridge piers. $J$. Hydraul. Res. 40(6): 717-729

[14] Briaud J L, Chen H C, Li Y and Nurtjahyo P 2004 SRICOSEFA method for complex pier in fine-grained soil. J. Geotech. Geoenviron. Eng. 130 (11): 1180-1191

[15] Debnath K and Chaudhuri S 2010a Bridge pier scour in claysand mixed sediments at near-threshold velocity for sand. $J$. Hydraul. Eng. 136(9): 597-609

[16] Debnath K and Chaudhuri S 2010b Laboratory experiments on local scour around cylinder for clay and clay-sand mixed bed. Elsevier Eng. Geol. 111(12): 51-61

[17] Debnath K and Chaudhuri S 2012 Local scour around noncircular piers in clay-sand cohesive sediment beds. Elsevier Eng. Geol. 151(10): 1-14

[18] Kho K T, Valentine E and Glendinning S 2004 An experimental study of local scour around bridge piers in cohesive 
soils. In: Proceedings of the 2nd International Conference on Scour \& Erosion, International Society of Soil Mechanics and Geotechnical Engineering (ISSMGE), London, UK

[19] Li Y, Briaud J L, Chen H C, Nurtjahyo P and Wang J 2002 Shallow water effect on pier scour in clay. In: First International conference on scour of foundation

[20] Link O, Klischies K, Montalva G and Dey S 2013 Effect of bed compaction on scour at piers in sand-clay mixture. $J$. Hydraul. Eng. 139(9): 1013-1019

[21] Molinas A and Hosny M M 1999 Effect of gradations and cohesion on bridge scour. vol. 4. Experimental study of scour around Circular Piers in Cohesive soils. FHWA-RD-99-186

[22] Najafzadeh M and Barani G A 2014 Experimental study of local scour around a vertical pier in cohesive soils. Scientia Iranica 21(2): 241-250

[23] Rambabu M, Narasimha Rao S and Sundar 2003 Currentinduced scour around a vertical pile in cohesive soil. Ocean Eng. 30(4): 893-920

[24] Salaheldin T M, Imran J, Kassem A and Chaudhry H M 2003 Scale physical modeling of local scour in cohesive soil. TRB Annual Meeting. Washington, D.C., January 12-16

[25] Ting F C K, Briaud J L, Chen H C, Gudavalli Rao, Perugu S and Wei G 2001 Flume test for scour in clay at circular pier. J. Hydraul. Eng. 127(11): 969-978

[26] Melville B W 1975 Local scour at bridge sites. Ph.D. Dissertation. University of Auckland, School of Engineering, New Zealand

[27] Dargahi B 1990 Controlling mechanism of local scouring. J. Hydraul. Eng. 116(10): 1197-1214

[28] Melville B M and Coleman S E 2000 Bridge Scour. Water Resources Publication, Littleton, pp. 550

[29] Guo J 2012 Pier scour in clear water for sediment mixture. $J$. Hydraul. Res. 50(1): 18-27

[30] Ahmad F and Rajaratnam N 1998 Flow around bridge pier. $J$. Hydraul. Eng. 124(3): 288-300

[31] Ali K H M and Karim O 2000 Simulation of flow around piers. J. Hydraul. Res. 40(2): 161-174

[32] Kothyari U C, Kumar A and Jain R K 2014 Influence of cohesion on river bed scour in wake region of piers. $J$. Hydraul. Eng. 14(1): 1-13

[33] Chabert J and Engeldinger P 1956 Etude des affouillements autour des pile de pont. Series A, Laboratoire Nationald'Hydraulique. Chatou, France (in French)

[34] Shen H W, Schneider V R and Karaki S 1969 Local scour around bridge piers. J. Hydraul. Div. ASCE 96(6): 1919-1940

[35] Sha Y Q 1965 Basic principles of sediment transport. $J$. Sediment Res. Beijing, China, 1(2): 1-54

[36] Zhang Rui-jin 1989 River and sediment mechanics. Beijing, China Water Resources and Hydropower Press, pp. 63-84 (in Chinese)

[37] Namjoshi A G 1992 Anticipated scour depth in non-alluvial/ clayey beds. In: Proceedings of International Seminar on Bridge Structure and Foundation Bombay Document 3. Conference Document 3 vol. 2

[38] Melville B W and Sutherland A J 1988 Design method for local scour at bridge pier. J. Hydraul. Eng. 114(10): 1210-1226

[39] Melville B W 1984 Live bed scour at Bridge Piers. J. Hydraul. Eng. 110(9): 1234-1247
[40] Ettema R, Kirkil G and Muste M 2006 Similitude of largescale turbulence in experiments on local scour at cylinder. $J$. Hydraul. Eng. 132 (1): 33-40

[41] Sumer B M, Fredsoe J and Christiansen N 1993 Influence of cross section on wave scour around piles. J. Waterway Port Coast. Ocean Eng. 119(5): 477-495

[42] Tison L J 1940 Erosion autour de piles de pont en riviere. Ann. Des Travaux Publics de Belgique 41(6): 813-871

[43] Larras J 1963 Profondcurs maximales d'crosion des fonds mobiles autour des piles en rivière. Ann. Ponts et Chaussées, Vl. 133(4): 411-424

[44] Paintal A S and Garde R J 1965 Effect of inclination and shape of obstruction on local scour. Roorkee University Res. J. 8(1\&2): 51-64

[45] Dietz J W 1973 Kolkbildung an einem krciszylindrischen Pfeilerpaar. Die Bautechnik 50(6): 203-208

[46] Melville B W and Raudkivi A J 1996 Effect of foundation geometry on bridge pier scour. J. Hydraul. Eng. 122(4): 203-209

[47] Richardson E V and Davis S R 2001 Evaluating scour at bridge. 4th edn. Hydraulic Engineering Circular No. 18 (HEC-18). Publication No. FHWA NHI 01-001, Federal Highway Administration, U.S. Department of Transportation, Washington, DC

[48] Laursen E M 1960 Scour at bridge crossings. In: Proceedings of ASCE, vol. 86, pp. 39-54

[49] Ettema R 1980 Scour at bridge pier. No. 216, School of Engineering, University of Auckland, Aukland, New Zealand

[50] Cheiw 1984 Local scour at bridge pier. PhD thesis, Auckland University, New Zealand

[51] Nicollet G and Ramette M 1971 Scour at bridge cylindrical piers. In: Proceedings of the 14th IAHR Congress, Paris, vol. 3, pp. 315-322

[52] Dietz J W 1972 Ausbildung von langen Pfeilern bei Schraganströmung am Beispiel der BAB-Mainbrücke Ed-dersheim; Mitt. blatt der Bundesanstalt für Wasserbau, Karlsruhe, No. 31, pp. 79-94

[53] Lacey G 1930 Stable channel in alluvium. Minutes Proc. Instit. Civ. Eng. 229(1930): 259-292

[54] Press W H, Flnnery B P, Teukolsky S A and Vetterling W T 1986 Numerical recipes-the art of scientific computing, Cambridge University Press, Cambridge, UK

[55] Briaud J L, Chen H C, Kwak, K W, Han S W and Ting F C K, 2001 Multiflood and multilayer method for scour rate prediction at bridge piers. J. Geotech. Geoenviron. Eng. 127(2): 114-125

[56] Indian Railway Standard 1985 Code of practice for the design of sub-structures and foundation of bridges. Research Designs and Standards Organisation, Lucknow

[57] IRC 1998 Standard specifications and code of practice for road bridges. Section 1, IRC: 5-1998

[58] IRC 2000 Standard specifications and code of practice for road bridges. Section VII, IRC: 78-2000

[59] Arneson L A, Zevenbergen L W, Lagasse P F and Clopper P E 2012 Evaluating scour at bridge. 5th edn. Hydraul. Eng. Circular No.18 (HEC-18). Rep.No. FHWA-HIF-12-003, Federal Highway Administration, U.S. Dept. of Transportation, Washington, D.C. 